\title{
Nikolo intaglio kao primjer značenja i važnosti dragoga kamena i njegove imitacije u staklu u antičkom periodu
}

IVANKa RIBAREVIĆ-NIKOLIĆ

Neovisna djelatnica

10-3020 Van Horne

H3S 1R2, Montréal, Québec

Canada

E-pošta: ivanka_rn@outlook.com
UDK: 739.2

Prethodno priopćenje Primljeno: 14. veljače 2018. Prihvaćeno: 30. svibnja 2018.

Sažetak

Interdisciplinarnim istraživanjem, prvenstveno gemologije i arheologije na primjeru nikolo intaglija, ukazujemo na važnost dragoga kamena u antičkom periodu. Ujedno pratimo pojavnost imitacije u staklu nikolo intaglija i ukazujemo na moguće simboličko značenje imitacije.

Ključne riječi: gemologija; arheologija; nikolo; dragi kamen; stakleni intaglio. 
Ivanka Ribarević-Nikolić - Nikolo intaglio...

\section{Uvod: o dragom kamenu, njegovoj uporabi, formi i metodo- logiji istraživanja}

Dragi kamen korišten je za izradu arheoloških artefakata, prvenstveno intaglija, kameja i sitne, najčešće portretne plastike, što objedinjujemo zajedničkim imenom gliptika, te kao važan, često primarni dio nakitnih cjelina, prstenja, ogrlica, narukvica, naušnica, te broševa, fibula ili pojasnih kopči. Također dragi kamen je čest i veoma važan dio dekoracije sakralnih ili profanih objekata poput križeva, relikvijara, knjiga, ikona, vladarskih kruna ili utilitarnih objekata različite namjene.

Dragi kamen može biti ukrašen tehnikom urezivanja - intaglio ili je likovna kompozicija izražena u plitkom reljefu - kameja, ili ponekad $\mathrm{u}$ visokom reljefu, najčešće u formi poprsja kao sastavni dio kompozicije jednoga prstena u cijelosti oblikovanoga od jednoga komada dragoga kamena, a također i kao minijaturna skulptura, najčešće glava ili bista. U svim slučajevima poliranje je završna etapa obrade materijala. ${ }^{1}$

Nadalje, dragi kamen može biti oblikovan kao kabošon ravne ili blago konveksne baze, najčešće ovalnoga oblika i kupolaste gornje površine ili rezan u različitim oblicima i varijacijama konveksnih ili ravnih ploha. Uglavnom slobodnog, ne sasvim pravilnog oblika ovalne ili kuglaste forme, dragi kamen je najčešće korišten kao samostalni element, perla. Samo je poliran i probušen kako bi bio ugrađen u nakitnu cjelinu uz pomoć žice ili korišten kao sastavni dio niza jedne ogrlice ili privjesak naušnice. Dragi kamen također može biti facetiran, što znači da je površina kamena obrađena u formi faceta, odnosno oblikovana plohama pravilnoga geometrijskog oblika, istih ili različitih dimenzija. ${ }^{2}$

Ponekad je ovaj dragocjeni materijal korišten u izvornoj, prirodno formiranoj i tipičnoj kristalnoj formi poput smaragda, što znači u

1 Grassin Geoffroy, "Le travail des gemmes au XIIIe siècle dans la Doctrina poliendi pretiosos lapides", u: Cahiers de civilisation médiévale, 42(166), 1999., str. 111-137. U ovom srednjovjekovnom tekstu detaljno je opisana i tehnologija obrade dragoga kamena zabilježena u kronološki znatno ranijim pisanim izvorima.

2 Ruslan I. Kostov - Olga Pelevina, "Complex Faceted and Other Carnelian Beads from the Varna Chalcholithic Necropolis: Archaeogemmological Analysis", u: Geoarchaeology and Archaeomineralogy, R. I. Kostov - B. Gaydarska - M. Gurova (ed.), Sofia, 2008., str. 67-72. 
formi heksagonske prizme, ili poput dijamanta u formi oktaedra nevelikih dimenzija. Također, dragi kamen može biti rezan u geometrijskim oblicima, koji naliče prirodnim kristalnim formama različitih minerala, koji su vjerojatno bili ishodište inspiracije za ovakvo oblikovanje. Izabrani geometrijski oblik ne mora biti i vrlo često nije odraz tipične kristalne forme u kojoj se mineral sreće u prirodi. ${ }^{3}$

Nadalje, kao što smo spomenuli, različite forme dragoga kamena mogu biti perforirane i uz pomoć žice ugrađene u jednu nakitnu cjelinu. Također, dragi kamen može biti učvršćen, odnosno stavljen u posebno pripremljena ležišta koja svojim oblikom prate jedinstveni oblik svakog kamena, a formirana su metalnim ramom koji pridržava kamen na također metalnoj podlozi koja je gradivni dio nekog objekta ili nakita.

Svi navedeni oblici mogu biti izrađeni od prirodnoga dragog kamena. Kada promjene podrazumijevaju samo oblikovanje i poliranje, takav materijal, budući da nije promijenio izvorne karakteristike, opisujemo kao prirodni dragi kamen. Zatim, artefakti mogu biti rađeni od dragoga kamena koji nosi tragove izvjesnih modifikacija, odnosno tretmana, gdje su na umjetni način, djelovanjem čovjeka, promijenjene neke od karakteristika prirodnoga materijala kako bi on postao atraktivniji. Vrlo često tretman podrazumijeva promjenu intenziteta boje ili promjenu izvorne boje prirodnoga dragog kamena. Takve preinake potrebno je identificirati i ukazati, kada je to moguće, na vidljive ili ponekad samo pretpostavljene modifikacije. Također, česte su imitacije određenih vrsta dragoga kamena. Imitacije mogu biti rađene u prirodnom materijalu, najčešće korištenjem druge vrste prirodnoga dragog kamena koji je jeftiniji ili pristupačniji na tržištu, ili korištenjem umjetnoga materijala, poput stakla. ${ }^{4}$

Uobičajeno, svi navedeni oblici dragoga kamena rađeni su rezanjem jednoga, cjelovitoga komada minerala. Međutim, postoje i slučajevi kada je jedan artefakt, kao što to može biti višeslojna i višebojna

3 Ruslan I. Kostov "Pentagon-dodecahedral and icosahedral artifacts in Antiquity: 3D five-fold symmetry applied to cultural heritage", u: Annual of the University of Mining and Geology St. Ivan Rilski, Humanitarian sciences and Economics, 57/IV, Sofia, 2014., str. 23-26; Louis Malleret, "Classification et nomenclature des 'perles' archéologiques en fonction de la symétrie minérale", u: Bulletin de l'École française d'Extrême-Orient, 51/1, 1963., str. 117-124.

4 Cornelius S. Hurlbut - George S. Switzer, Gemology, A Wiley-Interscience Publication, New York - Toronto, 1979., str. 1-5, 103-108. 
kameja, rađen od više komada dragoga kamena, najčešće iste vrste, ali različite boje. Takav dragi kamen nazivamo kompozitnim, preciznije, to može biti dublet ili triplet ovisno o broju slojeva koji spajanjem komponiraju materijal. Ovi asamblaži, što je također ime koje se koristi, mogu djelovati veoma uvjerljivo i neophodna je pažljiva gemološka analiza. Zanimljivo je spomenuti da mnoge vrste imitacija, tretmana i asamblaža imaju kontinuiranu povijesnu prisutnost od antike do danas, o čemu svjedoče i pisani izvori. ${ }^{5}$

Bilo likovnom porukom koju nosi jedan intaglio ili općim stilskim karakteristikama objekta čiji je sastavni dio dragi kamen, specifičnim načinom obrade ili jednostavno kakvoćom svoje materije, dragi kamen nosi poruke vremena, društva, vjerovanja, društvenoga statusa svoga vlasnika, ukazuje na trgovačke putove i razmjenu kako materijalnih tako i nematerijalnih vrijednosti, govori o kakvoći prirodnoga resursa iz kojega potječe, o tehnološkom razvoju i razmjeni ideja, prožimanju stilova, mitova i religija. Stoga, da bismo mogli sagledati i znanstveno interpretirati sve informacije koje nosi dragi kamen, potrebno je pristupiti istraživanju s polazišnoga aspekta više disciplina, prirodnih i humanističkih znanosti. Polazeći od artefakta kao materijalnoga dokaza čiju pripadnost određenom vremenu potvrđuje arheološka metoda istraživanja ili analogna stilska analiza, zatim gemološke identifikacije vrste i kakvoće materijala, te iznimno složenoga znanstvenog procesa arheogemoloških analiza kojima je cilj identificirati zemljopisno podrijetlo ili rudnik iz kojega potječe određeni dragi kamen, dobivamo višeznačne rezultate. U takvom interdisciplinarnom pristupu problematici, korištenjem različitih metoda istraživanja, svi dobiveni pojedinačni rezultati znanstveni su doprinos podjednako arheologiji, gemologiji i arheogemologiji.

Uključujući informacije i nomenklaturu koje nose povijesni pisani izvori pokušavamo komparativnim interdisciplinarnim metodama, koristeći suvremene nazive, identificirati dragi kamen u kojemu su izrađeni artefakti. Stilski i kronološki određeni, prioritetno arheološkom metodom istraživanja, ti objekti izrađeni u dragom kamenu materijalni su pokazatelj određenoga vremena i prostora, pa tako

5 Michael O'Donoghue (ed.), Gems, Their Sources, Descriptions and Identifications, Elsevier, Amsterdam - Tokio, sixt edition, 2006., str. 531-536, 545-547, 720-721, 729-732. 
možemo reći da je arheologija na znanstvenom portalu povijesnoga ishodišta gemologije i neizostavno arheogemologije. ${ }^{6}$

U tekstu koji slijedi akcentirat ćemo važnost dragoga kamena i pokušati ukazati na moguće simboličko značenje imitacije dragoga kamena. Izabrali smo kao primjer nikolo intaglio, i imitaciju u staklu nikolo intaglija. ${ }^{7}$ Ujedno ukazujemo na važnost i zadatost korištenja imena nikolo koje se veže isključivo uz ovaj kromatski specifičan oniks (Slika 1).

\section{Stakleni intaglio: terminologija i tehnologija izrade}

Staklo je najčešće korišten materijal za izradu imitacija dragoga kamena. Staklo može biti svih boja i svih razina prozirnosti, od prozirnog, poluprozirnog do neprozirnog. ${ }^{8}$ Također staklo može biti kori-

6 Najiscrpniji antički izvor informacija o dragom kamenu jest Naturalis historia Plinija Starijeg (Caius Plinius Secundus, 23. - 79. god. poslije Krista), čiju trideset sedmu knjigu posvećenu gemama citiramo u ovome radu: Pline L'AnCIEn, Histoire naturelle, Livre XXXVII, E. de SAInT-Denis (prijevod i komentar), Les Belles Lettres, Paris, deuxième tirage 2003., gdje je uz prijevod na francuskom jeziku tiskan i latinski original.

7 Zahvaljujemo recenzentima na pozornosti koju su posvetili ovome radu i uputama koje doprinose jasnijoj i boljoj prezentaciji ove teme. Ukazano je na neprihvatljivost imena "nikolit", te smo isključili iz teksta napomenu o rijetkoj uporabi ovoga imena. Također ne koristimo riječ "varijetet" kako bi bilo jasno da je nikolo ime koje se koristi za oniks specifične boje, a nije posebna vrsta kamena. Posebno želimo istaknuti naputak recenzenta da je neophodno konzultirati rad Erike Zwierlein-Dienl, Antike Gemmmen und ihr Nachleben, Berlin - New York, 2007., str. 308, koji može doprinijeti proširenju naših spoznaja o ovoj temi. Mi, na žalost, nismo u mogućnosti konzultirati preporučeni rad. Slobodni smo ukazati na članak iste autorice naslovljen "Gem Portraits of Soldier-Emperors", u: Chris EnTwistle - Nö̈L AdAms (ed.), Gems of Heaven, Recent Research on Engraved Gemstones in Late Antiquity c. AD 200-600, The British Museum, 2011., str. 149-162, sl. 38, 40. U istoj publikaciji ukazujemo na fotografije nikolo intaglija ili njegove imitacije u staklu, kako bismo dodatno istaknuli važnost nikolo intaglija i važnost identifikacije u smislu korištenja imena ovoga koloristički specifičnog oniksa kojeg nazivamo nikolo (str. 76, 102, 111, 118, 121, 128, 197, 229, 250, 254, 260), <http://britishmuseum. org/pdf/Gems_of_Heaven_online.pdf> (10.4. 2018.)

8 U opisu dragog kamena i podjednako stakla, važno je precizirati transparentnost - prozirnost, odnosno razinu u kojoj određeni materijal propušta svjetlo i analogno omogućava vidljivost nekoga objekta, teksta, slike smještenoga iza ili ispod danog materijala. Materijal je transparentan ili proziran kada je predmet ili tekst gledan kroz taj materijal jasno vidljiv, odnosno čitljiv. 
šteno u višeslojnim i višebojnim kompozicijama, neovisno o tomu jesu li one horizontalno koloristički slojevite ili je polikromija izražena na površini staklenoga intaglija, u geometrijski pravilnim poljima, pravocrtnim ili valovitim trakama ili pojasevima. Tako, staklo može imitirati i transparentnost i boju određenoga dragog kamena, što ovaj umjetni materijal čini vrlo podesnim za izradu imitacija. ${ }^{9}$

U većini slučajeva moguće je prepoznati vrstu dragoga kamena imitiranoga u neprozirnom staklu, uspoređujući imitaciju s postojećim repertoarom prirodnoga dragog kamena korištenoga u proizvodnji intaglija, kao što su ahat ili oniks. Međutim, u slučaju specifičnih staklenih višebojnih intaglija, rađenih u kombinaciji plavo-bijelo-zelenih pravilnih površina, standardno istoga tona i intenziteta plave i zelene boje, uvijek neprozirnoga stakla, upitan je izvor inspiracije njihove standardizirane polikromnosti. Uobičajeno je u arheološkoj literaturi precizirati boju i razinu prozirnosti kada su u pitanju intagliji rađeni u jednobojnom staklu, što je primjereno, imajući na umu da nije uvijek moguće pretpostaviti koji je od dragocjenih prirodnih materijala korištenih u gliptici zapravo imitiran. Također, u nakitu, često je jednobojno, negravirano staklo, ponekad ugrađeno zajedno sa skupocjenim prirodnim dragim kamenom.

Primijećeno je da pojmovi "staklo" i "staklena pasta" nemaju ujednačenu uporabu u stručnoj literaturi čija je tematika gliptika. Da bi se izbjegle nejasnoće, predloženo je korištenje pojma "stakleni intaglio" za sve kopije intaglija rađenih u ovom materijalu u antičkom periodu i analogno, "staklena pasta" za sve intaglije rađene u ovom materijalu u novodobnom periodu.

Plinije Stariji u trideset sedmoj knjizi Naturalis historia koristi izraz vitrum govoreći o staklu kao materijalu za izradu imitacija dragoga kamena. ${ }^{10}$ Ističući navedene informacije koje nalazimo kod Plinija Starijeg, predloženo je korištenje termina "stakleni intaglio" za intaglije antičkoga perioda, što mi slijedimo u ovome radu. ${ }^{11}$

9 Napomenimo da su boja i transparentnost dvije neovisne karakteristike. $\mathrm{Na}$ primjer, dragi kamen svijetloplave boje može biti ili proziran ili poluproziran ili neproziran. Stoga uz boju i razina prozirnosti treba biti dio deskripcije materijala.

10 Plin. NH 37.83, 98, 112, 117.

11 Alessandra Magni - Gabriella Tassinari, "Gemme vitree, paste vitree, matrice vitree, gualche osservatione margine dello studio delle raccolte glittiche di Verona e Como", u: Alti del primo convegno interdisciplinare sur vetro nei 
Ukažimo na još neka iznimno važna zapažanja vezana za višestru$\mathrm{ku}$ problematiku staklenih intaglija. Jedno od pitanja vezano je za dataciju imitacije u staklu. Upitno je jesu li stakleni intagliji istovremeni originalnom intagliju, odnosno njegovu likovnom prikazu koji kopiraju. Ponekad, primjetna je velika vremenska razlika između kreacije originalnog intaglija u prirodnom dragom kamenu i reprodukcije njegova slikovnog prikaza, zapravo kopije u staklu. Napomenimo, prioritetna je likovna kompozicija određenog intaglija koja će poslužiti za produkciju replika, dok odabir kakvoće stakla za izradu intaglija ne uvjetuje imitaciju specifičnoga dragog kamena, iako je primijećeno da se izvjesni motivi učestalije povezuju s određenom vrstom dragoga kamena i analogno njihovom imitacijom u staklu. Jednostavnije rečeno, staklom se imitira bilo koji dragi kamen, a likovni prikaz staklenog intaglija jest replika dobivena otiskom i stoga istovjetna originalnoj kompoziciji intaglija rađenog u dragom kamenu. ${ }^{12}$

Najčešće su za proizvodnju staklenih intaglija korišteni kalupi u terakoti u koju je motiv bio utisnut korištenjem originalnog intaglija izrađenog u dragom kamenu, otiskom novca ili uz pomoć matrice. Također poznati su i kalupi izrađeni u bronci. Nakon što je proces rada u kalupu završen, dodatno su oblikovani ili obrađivani rubni dijelovi intaglija. Najbolji primjerci staklenih intaglija bili su retuširani kako bi detalji figuralnoga prikaza bili jasniji. ${ }^{13}$

beni culturali e nell 'arte di ieri e di oggi, Parma, (2008.) 2009., str. 98, citirajući izneseni prijedlog Erike Zwierlein-Diehl koja definira kao "glasgemmen" replike u antičkom periodu i "glaspasten" kada su one produkt novodobnog perioda, što ima talijansku analogiju "gemme vitree, paste vitree"; Iva KAIć, "Intagliji iz zbirke Franjevačkog samostana u Imotskom", u: Istraživanja u Imotskoj krajini, Znanstveni skup Imotski (2011.), Hrvatsko arheološko društvo, sv. 29, Zagreb, 2015., str. 42 i bilj. 2, na hrvatskom jeziku, "staklo i staklena pasta", u navedenom kronološkom određenju.

12 HÉLÈnE GuIRAud, Intailles et camées de l'époque romaine en Gaule (Territoire français) $48^{e}$ supplément a Gallia, Paris, 1988., str. 44, 46, o imitaciji u staklu i odabiru dragog kamena koji se imitira.

13 H. Guiraud, Intailles et camées de l'époque romaine en Gaule, str. 33, sl. 11d, gdje je više kalupa različitog likovnog repertoara sačuvano na jednom komadu terakote iz Belgije, T. 2d; bilj. 22, 23, ukazujući na matricu iz Ordone, koja nosi reljefni prikaz "Rog izobilja". 
Ivanka Ribarević-Nikolić - Nikolo intaglio...

Kao primjer staklenoga intaglija, odnosno imitacije dragoga kamena u staklu, izabrali smo nikolo. Nikolo je crni ili tamnosmeđi oniks s tankim bjeličasto-svijetloplavim slojem. ${ }^{14}$

Nikolo je bio korišten isključivo za izradu intaglija. Nikolo intaglio rezan je na dva načina, koji, čini se, imaju i okvirni kronološki slijed. Imitacije u staklu nikolo intaglija također formom i koloristički oponašaju originalni nikolo intaglio.

\section{Nikolo - nicolo: o imenu i boji}

Nikolo je oniks, odnosno dvoslojni, mikrokristalasti kvarc (kremen), čiji gornji sloj ima specifičnu bjeličasto-svijetloplavu boju, a donji sloj je tamnosmeđe ili crne boje. ${ }^{15}$ Evidentan je izraziti kontrast ovih paralelnih horizontalnih slojeva. Koloristička različitost i pravilnost paralelnih slojeva tipična je za oniks općenito. Koloristička kontrastnost bila je osobito cijenjena. Jedino oniks poznat pod imenom nikolo ima ovu specifičnu kromatsku kombinaciju svijetloplavog gornjeg sloja i izrazito tamnog donjeg sloja (Slika 1).

Ime ovoga koloristički specifičnoga oniksa, nikolo - nicolo, dolazi od talijanskoga onicolo u značenju "mali oniks". ${ }^{16}$

U arheološkoj znanstvenoj literaturi uobičajeno se koristi ime nikolo za ovaj kromatski specifičan oniks. Brojan među arheološkim nalazima, nikolo je korišten za izradu intaglija, ali podjednako brojno zastupljen i kao imitacija u staklu.

Mi ćemo u daljnjem tekstu koristiti isključivo naziv nikolo, koji poput naziva sardoniks ili karneoloniks jasno određuje ovaj koloristički specifičan oniks. ${ }^{17}$

14 M. O'Donoghue (ed.), Gems, str. 833, "Nicolo - black or dark brown onyx with thin bluish white layer".

15 Maja Vrkljan - Vera Babić - Jasenka Taksić, Mineralogija, Udžbenik za srednje škole, Školska knjiga, Zagreb, 1998., str. 236, ime minerala "kvarc ili kremen"; M. O'Donoghue (ed.), Gems, str. 833.

16 Hodder M. Westrop, A Manual of Precious Stones and Antique Gems, London, 1874., str. 46, 104, ime nikolo dolazi od talijanskoga u značenju "mali oniks"; Charles W. KIng, Antique Gems: their origin uses and value, as interpreters of ancient history, and as illustrative of ancient art, London, 1860., str. 11-13, potvrđuje isto mišljenje, napominjući da je vezivanje imena ovoga specifičnog oniksa s osobnim imenom umjetnika "Nicolo" neosnovano.

17 Remza KoščEvić, Arheološka zbirka Benko Horvat, Muzej suvremene umjetnosti Zagreb i Institut za arheologiju Zagreb, Zagreb, 2000., str. 62-92, navodimo kao 
U iznesenim prijedlozima o mogućem antičkom imenu nikolo, uspoređujući ga s vrstama dragoga kamena sličnih karakteristika koje opisuje Plinije Stariji, iznesena je pretpostavka da je moguće nikolo istovjetan antičkom dragom kamenu koji Plinije naziva aegyptilla čije ime ukazuje, kako nam nadalje pojašnjava autor, na njegovo podrijetlo iz Egipta. ${ }^{18}$

Bogati arheološki nalazi nikolo intaglija ukazuju na popularnost ovoga dragog kamena, dodatno potvrđenu brojnim nikolo imitacijama u staklu. Kako precizira Hélène Guiraud, najveći broj imitacija u staklu imitira upravo nikolo. ${ }^{19}$

\section{Nikolo intaglio i imitacija u staklu nikolo intaglija: oblik}

Način rezanja nikolo intaglija podrazumijeva dva osnovna oblika. U oba slučaja, u načelu, površine gornjeg i donjeg sloja su ravne i paralelne. Razlika je izražena u načinu rezanja bočnih strana, gdje su one ravno rezane pod pravim kutom, ili skošene, rezane pod oštrim kutom. U prvom primjeru vidljiva je na površini samo plava boja gornjeg sloja nikolo intaglija. Drugim načinom rezanja istaknuta je kromatska kontrastnost kamena. U pogledu odozgo plavi sloj u centru okružen je tamnim sada vidliivim donjim slojem nikolo oniksa.

primjer izvanredne kolekcije nikolo intaglija. Svi nikolo (nicolo) intagliji identificirani su, nedovoljno precizno, kao oniks. (Napomenimo, oniks je mikrokristalasti kvarc (kremen) koji ima paralelne pravocrtne slojeve različitih boja.) Sve imitacije nikolo intaglija identificirane su kao "staklena pasta - imitacija nikoloa". Nikolo jest oniks specifične boje bjeličasto-svijetloplavoga sloja i izrazito tamnog smeđeg ili crnog sloja. Upravo nikolo, a ne bilo koji oniks, ima iznimnu važnost u rimskodobnoj gliptici i neophodno je koristiti ime nikolo u cilju jasne komunikacije. Nedostatak deskripcije, boje i brojnosti slojeva, ne dopušta razmišljanje o mogućim "različitim originalima" koji su imitirani u staklu ili o mogućem postojanju nikolo imitacije u prirodnom materijalu, promjenom boje (tretmanom) prirodnoga oniksa. Poznata je nikolo imitacija u staklu tamnoplave i plave boje, te crne i svijetloplave boje, što nadalje može voditi ka razmišljanju o prirodi imitiranoga originala. Imitiran u staklu može biti nikolo ili oniks kojemu je promijenjena boja i koji imitira nikolo. Vidjeti tekst koji slijedi i bilješke 25, 26.

18 Gisela M. A. Richter, Cataloque of Engraved Gems, Greek, Etruscan and Roman, Rome, 1956., str. 36; H. M. Westrop, nav. dj., str. 104, također po-

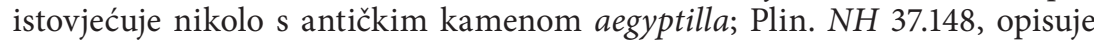
aegyptilla kamen kao "[...]uolgus autem nigra radice, caerulea facie; nomen a loco". Pojasnimo, cerulean, ili caerulean, opisuje se kao plava boja širokog tonaliteta između plave i azurne, odnosno azurne i nebo plave.

19 HéLÈne GuIRAud, Intailles et camées romains, Picard, Paris, 1996., str. 37. 
Napomenimo da postoje još neke minorne oblikovne karakteristike a izražene su u rezanju bočnih strana. Te različitosti su najvjerojatnije uvjetovane načinom ugradnje kamena u prsten, i ne utječu na spomenute dvije osnovne vizualne karakteristike nikolo intaglija.

Najčešće, likovni prikaz urezan je na plavom sloju čitavom njegovom debljinom, te je tako intaglio kompozicija očitovana kao crno na plavom. Također kompozicija može biti plitko urezana tako da ne doseže do donjeg tamnog sloja, te je površina intaglija u cijelosti ili gotovo monokromno plava. Uz navedeno, istaknimo, Arheološki muzej u Zagrebu posjeduje, ako ne izniman, svakako neuobičajen primjerak nikolo intaglija čije lice čini tamni sloj te je likovna kompozicija izražena kao plavo na tamnom. ${ }^{20}$

Prema H. Guiraud, najčešći način rezanja nikolo intaglija ističe kromatsku razliku na površini intaglija (Tabla 1, sl. 4-6). S kraja Republike ili u doba Augusta, odabrani oblik (Tabla 1, sl.1-3) otkriva samo gornji plavi sloj. ${ }^{21}$

Nikolo postaje popularan kamen za izradu intaglija počevši od 1. st. pos. Kr. i posebno u 2. st. pos. Kr. (Slika 2, 3). Tematski, prevladavali su figuralni prikazi božanstava, heroja i ratnika. Likovna kompozicija, duboko urezana, prikazana je kao tamna kontura na karakterističnoj nikolo svijetloplavoj površini. Početkom Carstva ovaj kamen oblikovan je na način da su rubovi rezani pod pravim kutom, dakle vidljiva je bila samo plava površina. ${ }^{22}$

Imitacije u neprozirnome staklu prate svojim načinom oblikovanja originalni nikolo intaglio imitirajući jedan gornji svijetli plavi sloj

20 Zahvaljujem dr. sc. Ivi Kaić koja mi je skrenula pozornost na ovaj primjer nikolo intaglija, koji je izvorno, autorski prezentiran kao dio tematske studije njezina doktorata. Također zahvaljujem dr. sc. Kaić na iznimnoj susretljivosti i vremenu koje je posvetila našem razgovoru koji je meni osobno pomogao da sveobuhvatnije sagledam složenu problematiku gliptike, kako s arheološkoga, kronološko-stilsko-ikonografskoga aspekta istraživanja, tako i s povijesnogemološkoga aspekta promatranja (identifikacija, imitacija i evaluacija dragog kamena kroz povijest) što je akcentirana tematika moga istraživanja.

21 H. Guiraud, Intailles et camées de l'epoque romaine en Gaule, str. 29, 31, sl. 9, P1-3, P5; crteži (I.RN.), Tabla 1, bazirani su na povijesnom pregledu i grafičkom prikazu H. Guiraud i fotografijama intaglija. Napomenimo, ovo je shematski prikaz, jer postoje i druge različitosti u rezanju bočnih strana nikolo intaglija koje nisu prikazane.

22 H. GuIRAud Intailles et camées romains, str. 32, sl. 17. 
i ispod njega tamni sloj. Prve imitacije u staklu potječu iz Augustova doba. ${ }^{23}$ Ovi stakleni intagliji, imitacije nikolo intaglija, rađene su po uzoru na postojeće nikolo intaglije (Slika 4,5). Također, često, urezani motiv odabranoga tematskog prikaza ne doseže do donjeg tamnog sloja stakla, tako da je slikovni prikaz monokromno plave boje. Uobičajeno rađeni s puno pažnje, stakleni intagliji svijetloplave boje imaju finu površinu, koju je moguće "usporediti s porculanom", kako je istaknuto. ${ }^{24}$

Ponekad nikolo imitacije imaju donji sloj rađen u staklu tamnoplave boje. Tamnoplava boja donjeg sloja nije tipična za prirodni nikolo, te ova činjenica, budući da imitacija u staklu teži idealnom oponašanju originala, navodi na mogućnost zaključka o postojanju dvoslojnih oniks intaglija čija boja je modificirana određenim tretmanom, kako bi bili slični nikolo originalu. Hélène Guiraud donosi potvrdu postojanja nikolo intaglija imitiranih tretmanom prirodnoga oniksa citirajući zaključke stručne analize nikolo intaglija trezora Eauze (Gers). Konstatirano je da je plava boja "nikolo intaglija" neprirodna, odnosno da je produkt tretmana prirodnog dvoslojnog oniksa sive i bijele boje. ${ }^{25}$ Svakako je zanimljivo, uz imitaciju u staklu, postojanje i nikolo imitacije i u prirodnom kamenu poput ove bazirane na promjeni boje koloristički drugačijeg (manje atraktivnog) oniksa. Primijenjen je, u antičkom periodu dobro poznat, tretman "šećer i kiselina", kojim je šećer, nakon što je u otopini meda i vode apsorbiran u porozni kamen, karboniziran djelovanjem kiseline termičkim postupkom.

23 Isto, str. 37, sl. 85.

24 H. Guiraud, Intailles et camées de l'epoque romaine en Gaule, str. 44, sl. 378, $432,449$.

25 Nismo uspjeli pronaći izvorno izvješće ili fotografiju ovih intaglija. Vjerujemo da buduće pažljive gemološke analize muzejskih kolekcija mogu otkriti slične primjerke tretmana oniksa, koji imitira nikolo. Ukazujemo na primjer intaglija iz Male Mlake "donjeg gotovo crnog sloja i gornjeg nešto svjetlijeg zatvoreno plavog" koji je upitno identificiran kao staklo, uz preporuku laboratorijske analize za preciznu identifikaciju. Autorica B. Migotti primjećuje mnoge tehničko-stilsko-kronološko-ikonografske karakteristike tipične za rad u kamenu i koje je teško povezati s procesom tipičnim za produkciju imitacija u staklu. Mi možemo samo pretpostaviti, jer nismo vidjeli materijal, da je moguće u pitanju nikolo imitaciji u prirodnom kamenu, tretmanom promjene boje prirodnog oniksa. Branka MigotTi, "Novopronađeni rimskodobni intaljo iz Male Mlake (Turopolje)", u: Opuscula archaeologica, vol. 25, 2001., str. 80-81, 85-86 i bilješka 4. Moja zahvala dr. I. Kaić koja mi je skrenula pozornost na ovaj znanstveni rad. 
Tako je karbonizirani šećer, sada crne boje, zapravo učinio izvorno svijetli oniks sivog i bijelog tona znatno tamnijim i sada sličnijim, ali ne identičnim, originalnoj nikolo boji. ${ }^{26}$

Svi navedeni detalji o ranim imitacijama nikolo intaglija, osobito činjenica da su uvijek imitirana oba sloja staklenog intaglija, odnosno obje boje, iako je bio izložen pogledu samo gornji sloj, nesumnjivo ukazuju na važnost imitacije i akcentiraju nastojanje da imitacija bude što je moguće ljepša i što je moguće sličnija idealnoj ljepoti prirodnog kamena. Prilikom izbora i kupovine intaglija sve vizualne karakteristike materijala, u ovom slučaju koloristički vrlo specifične i indikativne za nikolo, bile su vidljive i stoga zasigurno važne budućem korisniku intaglija. Kao što smo već ukazali, ovi precizno rađeni stakleni intagliji koji imitiraju nikolo intaglije datirani su u Augustovo doba i vjerojatno su imali visoku tržišnu vrijednost. ${ }^{27}$

Na prijelomu s2. na 3. st. pos. Kr. intenzivirana je produkcija imitacija nikolo intaglija u staklu, gdje su oba koloristička sloja vidljiva (Slika 5). Svijetloplavi gornji sloj stakla, koji nosi likovni prikaz, okružen je tamnim donjim slojem naglašeno ističući koloristički kontrast. Sada je to serijska produkcija uglavnom lošije kvalitete, granulaste površine pune rupica. Često je likovna kompozicija nedovoljno jasna, a plava boja gornjeg sloja slabijeg je intenziteta. ${ }^{28}$ Arheološki je potvrđen nalaz velikog broja ovakvih staklenih intaglija, datiranih u prvu polovicu 3. st. pos. Kr. U literaturi se često navodi nalaz dvadeset staklenih intaglija koji imitiraju nikolo intaglije nađenih u rimskom legionarskom kastrumu u Bonu i petnaest takvih staklenih intaglija vezanih uz nalaz sarkofaga Marcia Donata iz Narbone. ${ }^{29}$

26 H. Guiraud, Intailles et camées romains, str. 40, citirajući D. SchaAd (ed.), Le trésor d'Eauze. Bijoux et monnaies du IIIe siècle après J.-C., Toulouse, 1992.; Opis Plinijevog osvrta o ovom tretmanu (Plin. HN 37.195), uz neophodne dodatne komentare, donosi Kurt Nassau, "The Early History of Gemstone Treatments", u: Gems and Gemology, 20/1, Gemological Institute of America, 1984., str. 24; Također detaljniji osvrt na izvorni antički tretman i njegovu primjenu u 19. stoljeću daje C. W. KING, nav. dj., str. 11-13.

27 H. Guiraud, Intailles et camées de l'epoque romaine en Gaule, str. 33 i bilj. 36; Tab. 2, 28a, str. 217-218, navedena su 24 imitacije u staklu nikolo intaglija gdje je vidljiv samo gornji plavi sloj, u odnosu na 149 staklenih intaglija gdje su na površini vidljiva oba kromatska sloja.

28 H. GuIRAud, Intailles et camées romains, str. 37, sl. 11, 51, 66, 73.

29 A. Magni - G. TAssinari, nav. dj., str. 100, uz navedenu literaturu; H. GuiRAUD, Intailles et camées de l'epoque romaine en Gaule, str. 69, bilj. 105, Tab. 1, 
Istražujući primjere staklenih intaglija koji imitiraju nikolo, $\mathrm{H}$. Guiraud ukazuje na zanimljiv primjer originalnog primjerka intaglija koji je poslužio za izradu kalupa, što je ujedno omogućilo praćenje trgovine i distribucije staklenih replika. Tako je na primjerima staklenih intaglija koji imitiraju nikolo intaglije, datiranih u sredinu 3. st. pos. Kr. potvrđeno da svi potječu od istoga originala iz 1. st. pos. Kr., perioda tipičnog za procvat bukolikih prizora. ${ }^{30}$

Kako je primijećeno, distribucija staklenih intaglija rađenih uporabom kalupa, s početka 3. stoljeća, povezuje nalaze takvih staklenih intaglija nađenih $\mathrm{u}$ Francuskoj s analognim artefaktima nađenim u Njemačkoj. ${ }^{31}$

Važno je naglasiti da je Keln centar proizvodnje stakla zapadnih provincija Carstva, osobito masovne produkcije staklenih imitacija nikolo intaglija, koje su bile distribuirane širom sjevernih provincija Rimskoga Carstva, uključujući i Noricum na istoku. ${ }^{32}$

Zanimljivo je akcentirati neke od zaključaka koje iznosi Hélène Guiraud na primjerima artefakata iz Galije 3. i 4. st. pos. Kr., a koji su istovremeno odraz strujanja na području čitavoga Carstva. Kako to ističe autorica, a općenito je primijećeno u znanstvenoj literaturi, smanjena je produkcija intaglija i podjednako uporaba dragoga kamena. Izražena je prisutnost staklenih intaglija koji imitiraju nikolo. Prema mišljenju autorice, ova situacija još nije znanstveno, u cijelosti objašnjena. ${ }^{33}$ Proizvodnja intaglija vidljivo je smanjena krajem 3. st.

3a.8a.10a.12a.; Gertrud Platz-Horster, "Seals in Transition: their Change of Function and Value in Late Antiquity", u: Chris Entwistle - NoËL AdAms (ed.), Gems of Heaven, Recent Research on Engraved Gemstones in Late Antiquity c. AD 200-600, The British Museum, 2011., str. 222.

30 H. Guiraud, Intailles et camées de l'epoque romaine en Gaule, str. 73.

31 Hélène Guiraud, "Intaglios and Cameos from Gaul in the 3rd and $4^{\text {th }}$ Centuries AD", u: Chris Entwistle - Nö̈l Adams (ed.), Gems of Heaven, Recent Research on Engraved Gemstones in Late Antiquity c. AD 200-600, The British Museum, 2011., str. 129. Rasprostranjenost ovih intaglija ukazuje na liniju komerca potvrđenu arheološkim nalazima kako u Njemačkoj, tako i u Francuskoj. Detaljan pregled ovih intaglija donosi H. Guiraud, Intailles et camées de l'epoque romaine en Gaule, str. 73, sl. 445, 446, 447; A. MAGNI - G. TASsINARI, nav. dj., str. 102, uz iscrpnu bibliografiju, osobito ističući važnost ovih nalaza.

32 G. Platz-Horster, nav. dj., str. 222.

33 H. Guiraud, "Intaglios and Cameos from Gaul in the $3^{\text {rd }}$ and $4^{\text {th }}$ Centuries AD", str. 127. 
pos. Kr., vjerojatno kao odraz ekonomske krize očitovane u Carstvu, što je posljedica barbarskih upada. Također, analogno, smanjena proizvodnja intaglija u dragom kamenu očitovana je, čini se i poteškoćama da se dođe do izvora dragoga kamena. ${ }^{34}$ Međutim, odgovor na pitanje, zašto je dragi kamen "gotovo nestao" u kasnoantičkom periodu, još uvijek zahtijeva dodatna istraživanja. ${ }^{35}$

Gotovo u pravilu u bogatim ostavama datiranim u 4. st. pos. Kr. imitacije u staklu nikolo intaglija, nađene su zajedno s prirodnim nikolo intaglijima uz također prisutne intaglije rađene u drugim vrstama kamena. $\mathrm{U}$ istom periodu imitacije dragoga kamena $\mathrm{u}$ negraviranom staklu ugrađene su u nakit zajedno sa skupocjenim prirodnim smaragdom i biserom. ${ }^{36}$

Kako je to očitovano na primjeru dragocjenog oniksa nikolo, od samoga početka izrade nikolo intaglija, imitacija nikolo intaglija $\mathrm{u}$ staklu prati formom i tehnikom likovnoga prikaza originalni nikolo intaglio. Nesumnjivo kontinuitet uporabe ukazuje na važnost i vrijednost nikolo oniksa, ali isto tako čini se ne možemo umanjiti niti važnost ili značenje nikolo imitacije u staklu. ${ }^{37}$

Treba naglasiti da objekti rađeni u dragom kamenu, najčešće intagliji, ali podjednako i imitacija intaglija u staklu, nikada nisu hotimice uništavani i često su korišteni kao spolije u povijesnom kontinuitetu, iako drugačijega kulturološkog okružja i vjerovanja.

\section{Dragi kamen i njegova imitacija: važnost i simbolika}

Navedeni primjeri staklenih intaglija, njihova brojnost i rasprostranjenost, koju smo akcentirali na primjeru prirodnoga dragocjenog oniksa nikolo i njegove imitacije u staklu, ukazuje na važnost i zna-

34 Gemma Sena Chiesa, "Myth Revisited: the Re-use of Mythological Cameos and Intaglios in Late Antiquity and the Early Middle Ages", u: CHris Entwistle - Nö̈l Adams (ed.), Gems of Heaven, Recent Research on Engraved Gemstones in Late Antiquity c. AD 200-600, The British Museum, 2011., str. 229.

35 G. Platz-Horster, nav. dj., str. 221.

36 H. Guiraud, "Intaglios and Cameos from Gaul in the $3^{\text {rd }}$ and $4^{\text {th }}$ Centuries AD", str. 128, sl. 6-7, stakleni intagliji iz trezora Eauze, Gers.

37 H. Guiraud, Intailles et camées romains, str. 36-41, daje pregled uporabe sta$\mathrm{kla}$, ističući važnost toga materijala za izradu intaglija 
čenje imitacije dragoga kamena i očito višeznačne poruke koju ona može nositi. Jedan aspekt promatranja važnosti staklenoga intaglija je društveno-povijesni i analogno-ekonomski, što znači da je imitacija znatno jeftinija i pristupačnija na tržištu. Zasigurno je od veće važnosti vjerovanje u postojanje zaštitne magijske moći imitacije, što je, moguće, uvjetovalo i tržišnu ponudu. Imitacija u staklu nalik je originalnoj tvari, prirodnom dragom kamenu i njegovu slikovnom prikazu, koji imitacija, poput originala, također nosi. ${ }^{38}$

Važnost i vrijednost dragoga kamena potvrđuje kontinuitet uporabe antičkih intaglija, kako u kasnoj antici, tako i u srednjem vijeku, gdje poganska ikonografija, zastupljena na intaglijima, biva viđena na drugačiji način, sada primjereno duhu novog kršćanskog vremena i vjerovanja.

Ukažimo na zanimljiv primjer nikolo intaglija iz Augustova doba, na kojemu je vidliiva samo svijetloplava površina s urezanim crnim figurama dva satira, koji je ugrađen u prsten jednog franačkog plemića, nađen kao grobni prilog, datiran u prvu polovicu 6. st. pos. Kr. ${ }^{39}$ Slični primjeri su mnogobrojni. Poput intaglija rađenih u prirodnom kamenu, imitacije nikolo intaglija u staklu imaju kontinuitet uporabe. ${ }^{40}$

$\mathrm{Na}$ kraju osvrta o ovome iznimnom dragocjenom kamenu, nikolo oniksu, kojeg smo uzeli kao primjer, i svakako podjednako značajnim njegovim imitacijama u staklu, specifične kromatske game plavog i izrazito tamnog tona, hipotetski ukazujemo na moguće smjernice $\mathrm{u}$ razmišljanju o vrijednosti i značenju imitacije dragoga kamena.

Nastojimo pojasniti složeni odnos simboličkoga značenja tvari dragoga kamena i slikovnoga prikaza koji dragi kamen nosi prezentirajući, veoma sažeto, publicirane zaključke istraživanja i analize dva pisana izvora. Jedan je lapidarij Cyranides, a drugi je medievalni

38 Mišljenje o magijskoj moći stakla, odnosno imitacije dragocjenoga kamena u staklu i imitacije općenito, poznato je u stručnoj literaturi. Mi ćemo pokušati ukazati na moguće objašnjenje ovakva vjerovanja.

39 G. Platz-Horster, nav. dj., str. 226, sl. 6, muški prsten iz groba 1782, Krefeld-Gellep.

40 Genevra Kornbluth, "Roman Intaglios Oddly Set: The Transformative Power of the Metalwork Mount", u: Chris Entwistle - NoËL Adams (ed.), Gems of Heaven, Recent Research on Engraved Gemstones in Late Antiquity c. AD 200-600, The British Museum, 2011., str. 253, sl. 19, disk-fibula s ugrađenim staklenim intaglijom koji imitira nikolo s prikazom Viktorije. 
tekst čiji autor je bizantski filozof Michael Psellos. Oba teksta bazirana su na znatno ranijim pisanim izvorima i tematski se osvrću i na pitanje odnosa likovnoga prikaza, neovisno o njegovoj ikonografskoj temi, u odnosu na snagu i moć materije određenoga dragog kamena na kome je urezana likovna poruka.

Lapidarij Cyranides kompilacijski je rad o medicinskim i magijskim osobinama biljaka, ptica, riba, četveronožaca i dragoga kamena. Latinski prijevod grčkog originala pripada imperijalnom periodu. ${ }^{41}$

Istražujući odnos medicine i religije na magijskim gemama, Maria G. Lancellotti prezentira informacije zapisane u lapidariju Cyranides. Prema navedenom tekstu, dragom kamenu je pripisano nepromijenjeno terapeutsko djelovanje, što je trajna karakteristika tvari dragoga kamena. Dodavanjem određenog likovnog prikaza ta karakteristika biva "još izraženija i uvećana tako da vlasnik toga dragog kamena, sada ima specifične osobne dobrobiti, značajnije od jednostavnih tjelesnih učinkovitosti". ${ }^{2}$ Također, autorica u kontekstu iste tematike citira i tekst Orphic lithica, vjerojatno iz 2. st. pos. Kr., koji ukazuje na činjenicu da je dragi kamen u biti svoje materije, neovisno o tome ima li "sliku" već po samoj svojoj prirodi jedan element koji posreduje s božanstvom. ${ }^{43}$

Osvrnimo se na jedan važan i složen koncept filozofskoga razmišljanja poznat kao sympatheia koji je imao značajne uplive na način razmišljanja i viđenja specifičnih karakteristika dragoga kamena kako u antičkom društvu, tako i ranokršćanskom, te dalje u širokom vremenskom rasponu uključujući bizantsko kršćansko društvo 11. stoljeća. Katerina Ierodiakondu povijesno analizira ovaj složeni filozofski koncept od antičkih filozofa preko neoplatonista nadalje, akcentirajući način njegove prilagodbe i aplikacije kroz traktate bizantskoga filozofa Michaela Psellosa u 11. stoljeću. ${ }^{44}$

41 Prema istraživanjima koje donosi Maria Grazia Lancellotti, "Medecine et religion dans les gemmes magiques", u: Revue de l'histoire des religions, 218/4, 2001., str. 436 i bilj. 38.

42 Isto, str. 437-438 (pod nazivom lapidaires Cyranides, u literaturi se spominje i kao Kyranides).

43 Isto, str. 434, 451, bilj. 96, pod naslovom Lapidaire d'Orphée.

44 Katerina Ierodiakondu, "The Greek Concept of Sympatheia and its Byzantine Appropriation in Michael Psellos", u: Paul Magdalino - Maria Mavroudi (ed.), The Ocult Science in Byzantium, La pomme d'or, Geneve, 2006., str. 97-117. 
Iako smo već ukazali na kolorističku preciznost s kojom su rađene kopije intaglija u staklu, slijedeći uzore nikolo originala, važno je ponovo se podsjetiti. Antje Bosselmann-Ruickbie osobito naglašava činjenicu da su umjetnici i lapideri proizvođači gema, bili svjesni važnosti konceptualnoga odnosa između tvari ili materijalnoga i vizualnoga, što je zapravo bit koncepta koji se može primijeniti na mnoge magijske i religijske aktivnosti. ${ }^{45}$

Navedena zapažanja važna su za razumijevanje principijelne ideje spomenutoga i filozofskoga koncepta sympatheia.

Prema filozofskome konceptu sympatheia "sličnost proizvodi sličnost", a stvari koje su jednom bile u kontaktu nastavljaju djelovati jedna na drugu i na distanci iako je fizički kontakt prekinut. ${ }^{46}$

Razmišljajući o značenju ovoga filozofskog načela čija je idejna prisutnost, više ili manje konceptualno modificirana, dugog trajanja i uz to u kulturološki i religijski različitom okružju, ukazujemo na moguće objašnjenje kojim bi značenje imitacije jednoga dragog kamena imalo istovjetnu snagu djelovanja kakvu nosi izvorni, prirodni dragi kamen. Kao odabrani primjer u ovome radu, uzeti su nikolo intagliji rađeni u prirodnom kamenu i evidentno ne od manje važnosti, imitacije nikolo intaglija u staklu. Veliki broj ovakvih staklenih intaglija potvrđuje postojanje vjerovanja u značenje i specifičnu zaštitnu moć ove imitacije, koja zasigurno nadilazi njezinu realnu materijalnu vrijednost.

Tako, u našem hipotetskom tumačenju filozofskoga koncepta sympatheia, imitacija u staklu nosi sličnost, znači stakleni intaglio koji imitira nikolo sličan je, po karakteristikama, nikolo prirodnom kamenu. Slikovna poruka koju uvijek nosi intaglio, dobivena je otiskom originala rađenoga u dragom kamenu. Originalni dragi kamen zajedno sa slikovnim prikazom, bio je u kontaktu s medijem koji služi za proizvodnju intaglija u staklu, te tako i nadalje, sada na distanci i

45 Antje Bosselmann-Ruickbie, "The symbolism of Byzantine Gemstones: Written Sources, Objects and Sympathetic magic in Byzantium", u: AlexanDra Hilgner - Susanne Greiff - Dieter Quast (ed.), Gemstones in the First Millennium AD, Mainz, 2017., str. 300; M. G. LANCELlotti, nav. dj., str. 442, isto značenje u kontekstu strategije medikalne učinkovitosti.

46 K. Ierodiakondu, nav. dj., str. 97; A. Bosselmann-Ruickbie, nav. dj., str. 300-301, koristi termin "sympathetic magic" u istom značenju. 
posredno, prenosi snagu djelovanja izvorne materije. Tako imitacija dragoga kamena, slična originalu, noseći uz to i kopiju slike originalnoga intaglija, posjeduje sve nevidljive energetske karakteristike poput originala.

Svakako ova pretpostavka zahtijeva daljnja istraživanja koja će prvenstveno biti bazirana na gemološkoj analizi stilski i kronološki određenih muzejskih artefakata i osobito na identifikaciji imitacija dragoga kamena, uz podjednako važne informacije koje nose pisani izvori, te filozofske i antropološke studije. 


\title{
Nicolo intaglio as an Example of Significance and Symbolism of Gems and Their Glass Imitation in the Ancient World
}

\author{
Summary
}

An interdisciplinary approach to the research of gemmology and archaeology has discovered a variety of information which simultaneously enrich the achievements of both disciplines. This paper highlights the importance of gems, especially in the Ancient World. From the gemmological aspect, a gem is natural if all of its natural features are preserved. Also, we describe gems with some of their original characteristics modified in certain treatments, most frequently the change of natural gem colour. Furthermore, we show how the imitations of gems are created with the use of natural or artificial materials.

Nicolo is taken as an example. It is onyx, of specific bluish white upper layer and very dark brown or black lower layer. It is assumed that nicolo can be identified with the antique stone that Pliny the Elder called aegyptilla. Nicolo became popular stone for intaglio carving at the time of the Empire, especially since the Augustan era, and was continuously used until the late antiquity. At the same time, imitations of nicolo intaglio in glass were produced which, with the colour (light blue and black combined) and the shape, followed the changes of the cutting techniques of the original intaglio. The main changes of shape were shown in a variety of nicolo cutting methods, with one or both colours of the stone being visible on the surface. When the edges are cut at right angles, only the upper blue layer of stone is visible on the surface of the intaglio. Nicolo intaglio with the edges cut at acute angles can contrast the colours of both layers of the stone. As a result, the blue colour in the centre, always containing a picture, is surrounded by darker colours of the lower layer of the stone.

Glass imitations of nicolo intaglio were found in the combinations of light blue and dark blue. Dark blue colour is not typical for natural nicolo or natural onyx in general. With the "sugar-acid" treatment, the onyx of grey and white colours was changed to resemble nicolo onyx, and probably this atypical colour combination of different blue shades was imitated in glass. It is believed that precious stone has a supernatural protective power manife- 
sted in its specific substance and its invisible energy. The long continuity of making and using nicolo intaglio and their imitations points to the importance of this precious stone as well as its imitation. We would like to point out that an imitation, same as natural precious stone, possesses the equal supernatural power.

A philosophical concept of sympatheia was taken as an example, according to which "likeness produces similarity", meaning that the objects which were once in contact continue to impact each other at a distance, even though physical contact was interrupted. Thus, according to the philosophical concept of sympatheia, the glass imitation shows resemblance, i.e. a glass intaglio that imitates nicolo, is similar to nicolo stone. The picture message which is always present in intaglio, was obtained by imprint of an original precious stone. Thus, the original precious stone, together with the picture, was in contact with a medium used to produce glass intaglio, and therefore, even at distance and indirectly, conveys the acting power of the original substance. Consequently, the imitation possesses all the invisible energy features as the original.

Certainly, this assumption requires further research, primarily based on the gemmological analysis of stylistic and chronological typology of the museum artefacts and the identification of precious stone imitations, with equally important information from written sources as well as philosophical and anthropological studies.

Keywords: gemmology; archaeology; nicolo; gems; glass intaglio. 


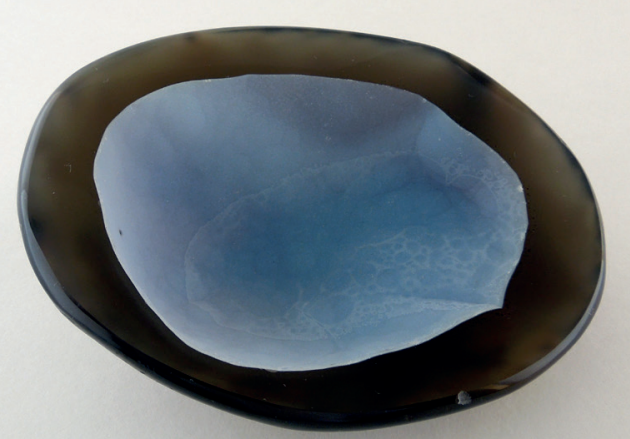

Slika 1. Nikolo (nicolo): mikrokristalasti kvarc osobite polikromije tamnosmeđeg (na slici) ili crnog i svijetloplavog sloja; prirodni oblik s poliranom površinom reza, $9,5 \times 7 \times 2,5 \mathrm{~cm}$, (fotografija R. Nikolić)

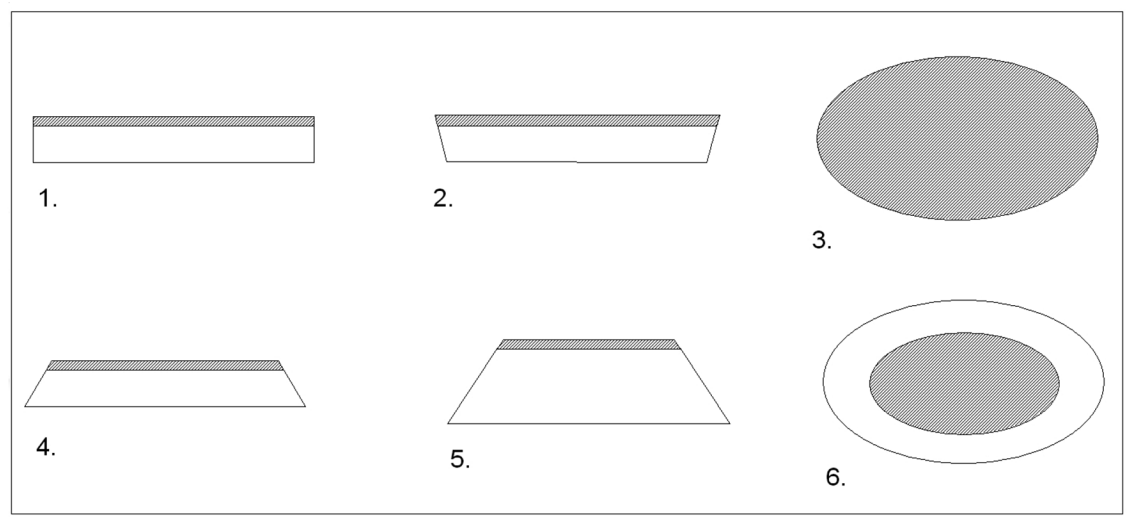

Tabla 1. Grafički prikaz načina rezanja nikolo intaglija: sl. 1, 2, oblici koji ističu monokromno plavu površinu sl. 3; sl. 4, 5, oblici koji ističu nikolo polikromiju plavog sloja u središtu i tamnog na rubovima sl. 6. 
Ivanka Ribarević-Nikolić - Nikolo intaglio...

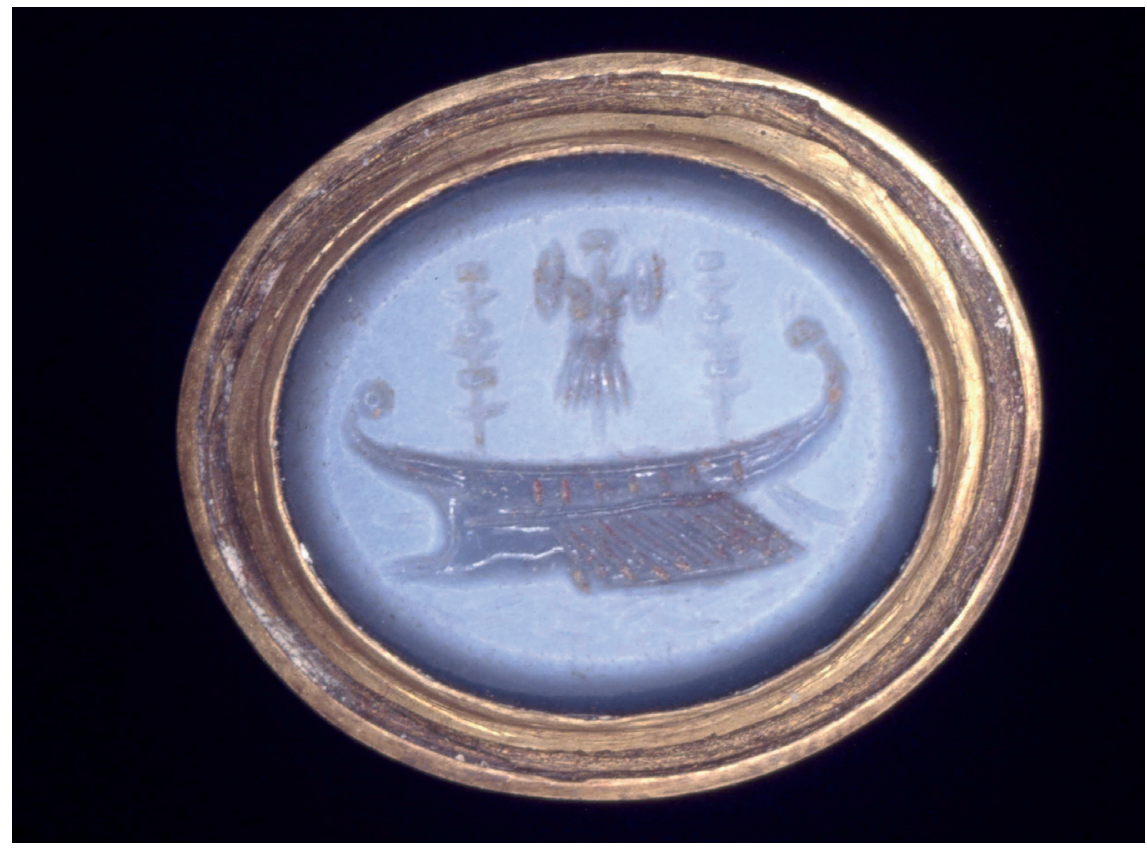

Slika 2. Nikolo intaglio, 15 x 13 mm, 1. st. prije Kr., (prikaz ratnog broda), London, British Museum, reg. number: 1865.0712.195 Ljubaznošću Courtesy @ Trustees of the British Museum

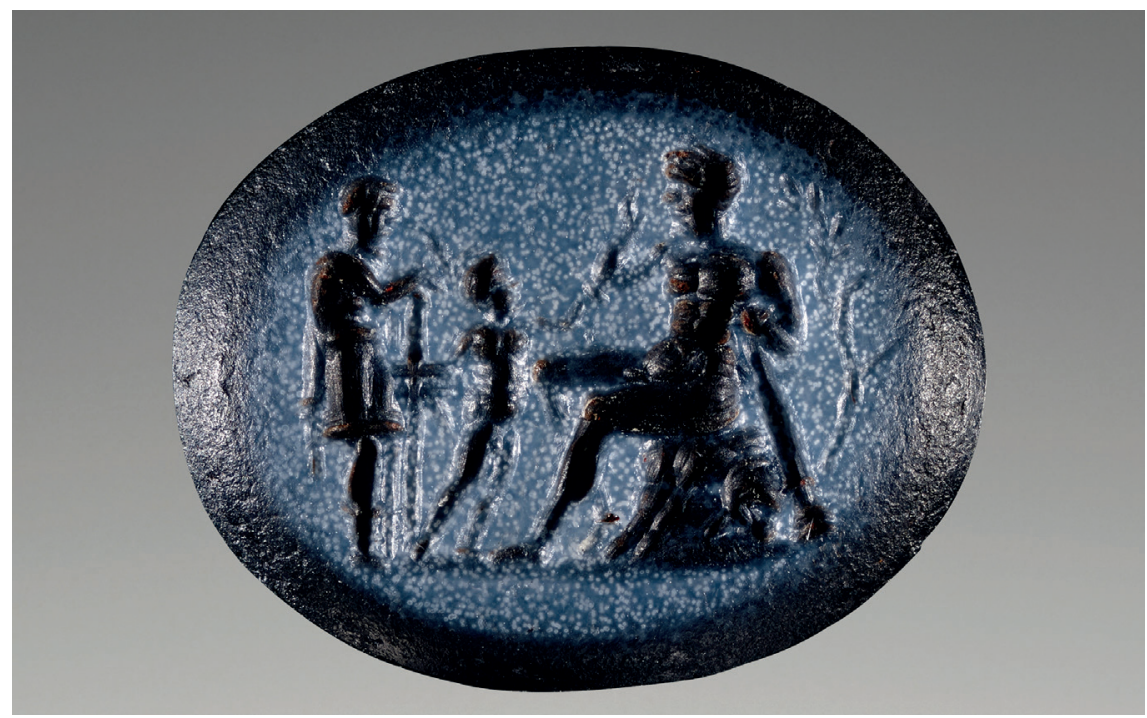

Slika 3. Nikolo intaglio, 14 x 11 x 4 mm, 1. - 2. st. pos. Kr., (prikaz Herakla i Telefa), The J. Paul Getty Museum, object number: 82. AN.162.57 Ljubaznošću Digital image courtesy of the Getty's Open Content Program 


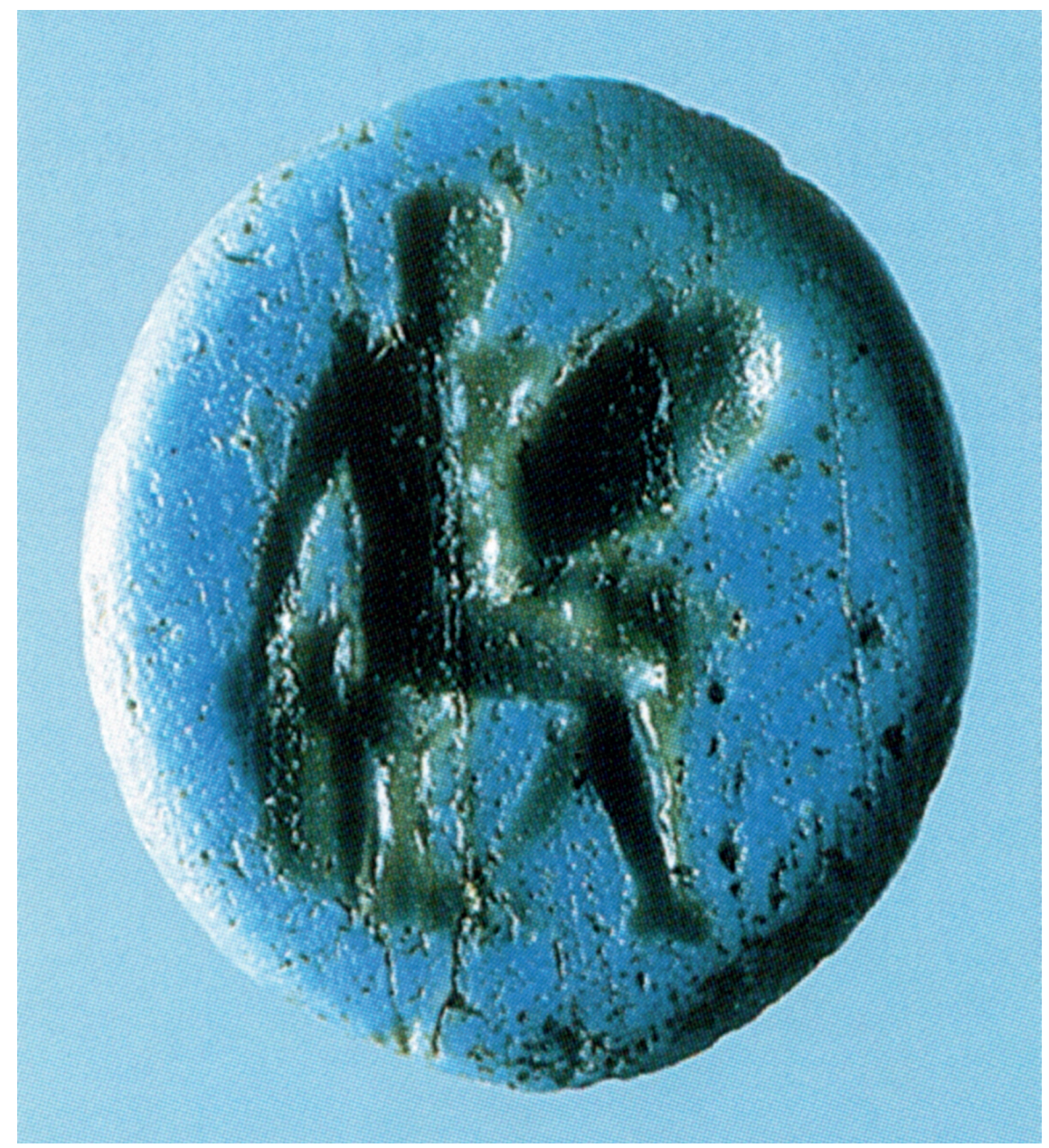

Slika 4. Staklo - imitacija nikolo intaglija, $11 \times 10 \times 2 \mathrm{~mm}$, bez datacije (prikaz ratnika). Ljubaznošću Muzeja suvremene umjetnosti Zagreb, Arheološka zbirka Benko Horvat inv. br. 550. Izvor: Remza Koščević, Arheološka zbirka Benko Horvat, kat. 68, Muzej suvremene umjetnosti Zagreb i Institut za arheologiju Zagreb, Zagreb, 2000. 
Ivanka Ribarević-Nikolić - Nikolo intaglio...

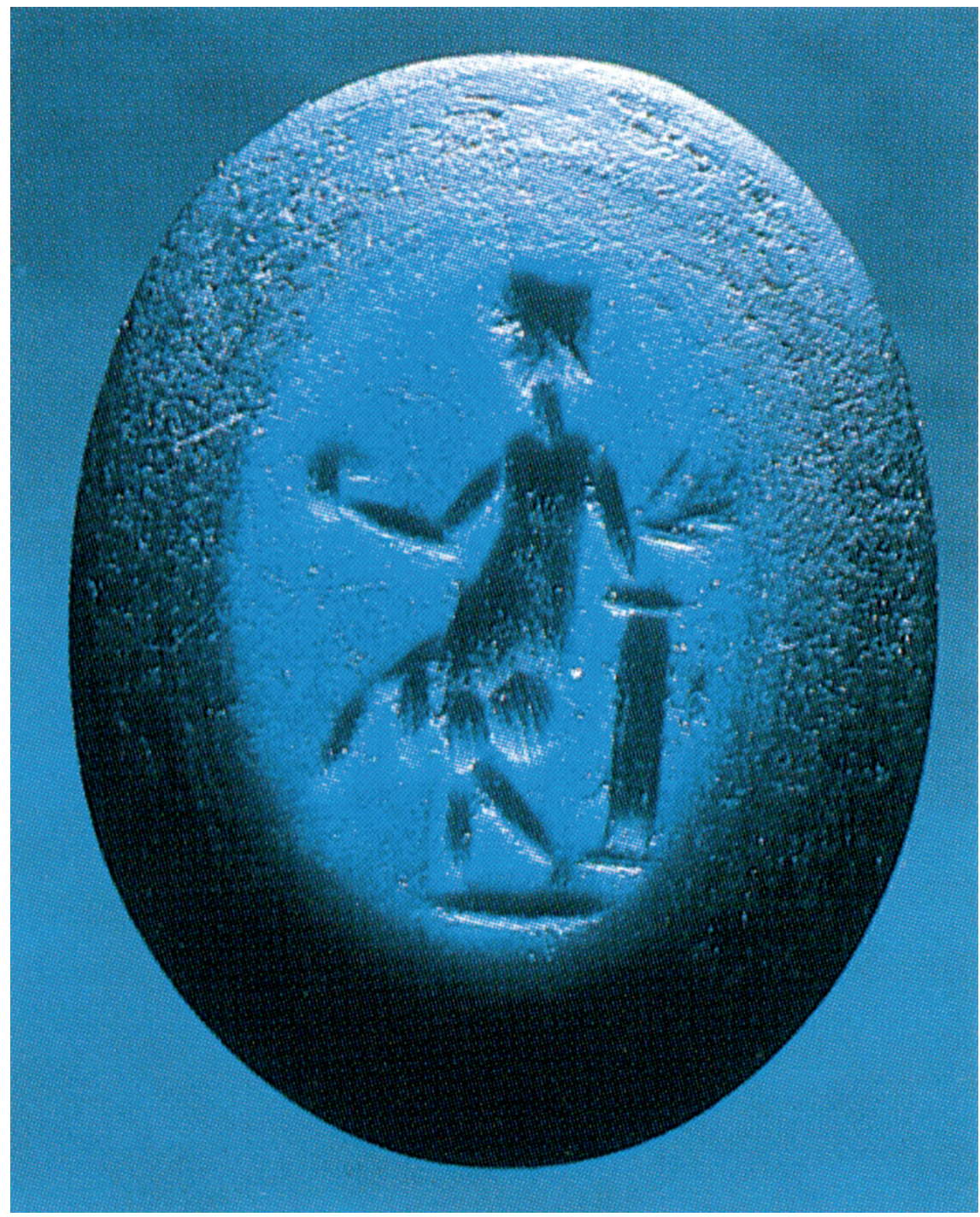

Slika 5. Staklo - imitacija nikolo intaglija, $10 \times 7.5 \times 3.5$ mm, 2. - 3. st. pos. Kr., (prikaz Venere Victrix). Ljubaznošću Muzeja suvremene umjetnosti Zagreb, Arheološka zbirka Benko Horvat inv. br. 552. Izvor: Remza Koščević, Arheološka zbirka Benko Horvat, kat. 43 Muzej suvremene umjetnosti Zagreb i Institut za arheologiju Zagreb, Zagreb, 2000. 